\title{
Impact of Plant Growth Regulators on Yield and Yield Components in Rice (Oryza sativa L.) Under Field Conditions
}

\author{
Abdul Samad Soomro ${ }^{1 *}$, Abdul Sattar Soomro², Shabana Naz Mazari ${ }^{3}$ \\ ${ }^{1}$ IPM Research Institute @ Quaid e Awam Agriculture Research Institute, Larkana Pakistan \\ ${ }^{2}$ Post Harvest Research Institute, Rice Research Center Dokri, Pakistan \\ ${ }^{3}$ Shaheed Zulfiquar Ali Bhuto Agricultural College, Dokri campus of SAU, Tandojam Pakistan
}

\section{Article Information}

Received: 01 July 2020

Revised version received: 15 September 2020

Accepted: 18 September 2020

Published: 29 September 2020

\section{Cite this article as:}

A.S. Soomoro et al. (2020) Int. J. Appl. Sci. Biotechnol. Vol 8(3): 318-322. DOI: 10.3126/ijasbt.v8i3.31611

\section{*Corresponding author}

Abdul Samad Soomro,

IPM Research Institute @ Quaid e Awam Agriculture Research Institute, Larkana Pakistan

Email: asamadsoomro@yahoo.com

Peer reviewed under authority of IJASBT

(C) 2020 International Journal of Applied Sciences and

Biotechnology

\section{OPEN ACCESS}

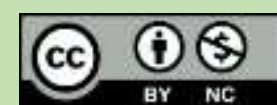

This is an open access article $\&$ it is licensed under a Creative Commons Attribution Non-Commercial 4.0 International

(https://creativecommons.org/licenses/by-nc/4.0/)

\begin{abstract}
The exercise of using (PGRs), especially Gibberellic acid and in field of agriculture has become commercialized in some of the country including Pakistan. Number of different crops are being treated by farmers mostly vegetables; currently evaluated in rice crop through foliar application at different intervals to evaluate their efficiency at different doses. Results revealed that there was no significant difference in crop maturity compared with control. Plant height was variable among treated plots, highest plant height was recorded $(121.2 \mathrm{~cm})$ in 2017-18 experiment in T-3 Gibberellic acid @ 12 grams/acre while minimum $(96.2 \mathrm{~cm})$ in $2016-17$ in T-7 Control. Tillers/hill was increased, and maximum counted 18.5/hill in T-3 Gibberellic acid @ $10 \mathrm{gms} /$ acre whereas $11.9 /$ hill was recorded in T-7 Control. Grain filling was obvious recorded with significance; counted 83 percent in T-5 Naphthalene acetic acid treated $100 \mathrm{ml} /$ acre whereas average minimum $(71.3 \%)$ was recorded in T-7 Control. Not only plant development was modified by the treatments but yield was also increased average maximum (3228kgs/acre) with 19.61 percent was recorded in T-5 Naphthalene acetic acid @ 100ml/acre.
\end{abstract}

\section{Introduction}

Rice (Oryza sativa L.) is a staple food (Shaikh et al., 2011) consumed by approximately 62.8 percent of the world's population; performing as a good source of calories taken by the peoples of the world; mostly in Asia with 29.3 percent (Timmer, 2010). In Pakistan it occupies $10 \%$ over all cultivated area (Shaikh et al., 2011). Plants are known as sessile and are not able to travel to the place for their comfort. As a result, different processes like growth and development are significantly exaggerated; mostly by high temperature stress is considered as one of the most harmful aspect (Lobell and Field, 2007). Currently rise in temperature is one of the most important global issues causing stress in cultivated plants (IPCC 2007). No doubt that rice plant has high tolerance to sustain high temperature during vegetative stage, but defenselessness observed when the temperature rises during the phase of reproduction especially when its start bearing flowers (Yoshida et al., 1981; Prasad et al., 2006). Pollination reduction and increased spikelet sterility are generally caused by night raised temperature ultimately results low grain yield (Jagadish, 2010). Different plant growth regulators applied 
for inducing heat tolerance of rice plant (Fahad et al., 2015). Gibberellic acid $\left(\mathrm{GA}_{3}\right)$ known as a growth regulator used to stimulate enzyme production for mobilization of seed reserves in germinating grains and stimulates growth of intact plants (Salisbury and Ross, 1992; Arteca, 1995). In rice, application of $\mathrm{GA}_{3}$ as seed treatment significantly improves germination percentage, seedling emergence and seedling height (Asborno et al., 1999). Naphthalene acetic acid generally shortened NAA with the formula $\mathrm{C}_{10} \mathrm{H}_{7} \mathrm{CH}_{2} \mathrm{CO}_{2} \mathrm{H}$ is an organic compound and known as a plant hormone, belongs to auxin family (Dimitrio et al., 2008). NAA a synthetic growth regulator has established it's prospective that in apposite concentration. NAA affects the growth and yield of a number of plants (Chhonkar and Singh 1959). Plant defense response against number of biotic and a biotic stress increased due to physiological response of plant growth regulators through foliar application (Walia et al., 2007).

In recent years environment; especially the temperature and humidity affected adversely to rice crop in Sindh, Pakistan. Pollen formation and grain filling was not obvious and ultimately yield losses were observed heavily. Plant Growth Regulators are one of the sources to stimulate the growth and development process with ease. Naphthalene acetic acid (NAA) and Gibberellic acid $\left(\mathrm{GA}_{3}\right)$ were tested on different doses through foliar application to find their effects on Growth, development and yield attributes of Rice crop under field conditions.

\section{Materials and Methods}

The experimentation was carried out at Department of Plant Physiology, Rice Research Institute, Dokri Larkana Pakistan during Kharif 2016-17 and 2017-18 for evaluation of different plant growth regulators and their effective dose. The research trial was designed in RCBD with three replications and seven treatments. Plot Size was measured $32.4 \mathrm{~m}^{2}$ with 27 plants entries/row and 30 plants were planted in each row.

Two different plant growth regulators were applied for determination of their impact. $1^{\text {st }}$ foliar application was given after 30 days of transplanting; other two foliar applications were applied with 20 days interval after applying $1^{\text {st }}$ one and tested the effectiveness of plant growth regulators on yield and yield attributes. Growth parameters; 90\% maturity and Plant height (in centimeters) were recorded and analyzed through mean, different yield parameters tillers/hill, grain filling per spike were recorded by simple percentage formula

$$
\text { Spikelet }(\%)=\frac{\text { Number of filled spikelet }}{\text { Total spikelet per spike }} \times 100
$$

Yield/ Acre and yield increase percentage were also recorded for the determination of both PGRs effect in growth, development and yield of rice crop. Gibberellic acid- $\left(\mathrm{GA}_{3}\right)$ was applied 08,10 and 12grams/Acre respectively and Naphthalene acetic acid-(NAA) plots were treated by 80,100 and $120 \mathrm{ml} /$ Acre and compare with untreated (Control).

\section{Results}

\section{Growth Attributes}

\section{A. 90 percent maturity}

The results shown that; there was no significant difference among the treated plots in terms of maturity. All the treated plots and control were mature almost at the same time. Average maximum late maturity was observed in T-3 Gibberellic acid @12gms/Acre (89 days) whereas control consumed 84.35 days (Table 1 ).

\section{B. Plant Height}

$1^{\text {st }}$ Foliar application (after 30 days of transplanting) of Gibberellic acid earlier shown increase in inter-node length among all the treatments of $\mathrm{GA}_{3} @ 08,10$ and 12 grams/Acre respectively; but later there was no significant difference in inter-node length after $2^{\text {nd }}$ and $3^{\text {rd }}$ application. T3Gibberellic acid @12gms/Acre shown highest Plant height $(115.85 \mathrm{~cm})$ followed by T2-Gibberellic acid @ 10gms $(109 \mathrm{~cm})$ compare to control $(97.7 \mathrm{~cm})$ all the treatment including control (Table 1).

Table 1: Effect of foliar applications of PGR on Growth components.

\begin{tabular}{|l|l|l|l|l|l|l|l|}
\hline \multirow{2}{*}{ S. N. } & \multirow{2}{*}{ Treatment } & \multicolumn{2}{|l|}{$\mathbf{9 0}$ Percent Maturity } & \multicolumn{3}{l|}{ Plant Height in Cm } \\
\cline { 3 - 8 } & & $\mathbf{1}^{\text {st }}$ Year & $\mathbf{2}^{\text {nd }}$ Year & Average & $\mathbf{1}^{\text {st }}$ Year & $\mathbf{2}^{\text {nd }}$ Year & Average \\
\hline $\mathbf{1}$ & Gibberellic acid @ 08gms & 85.7 & 88.7 & $\mathbf{8 7 . 2}$ & 102.2 & 103.7 & $\mathbf{1 0 2 . 9 5}$ \\
\hline $\mathbf{2}$ & Gibberellic acid @ 10gms & 85.0 & 86.5 & $\mathbf{8 5 . 7 5}$ & 106.5 & 111.5 & $\mathbf{1 0 9}$ \\
\hline $\mathbf{3}$ & Gibberellic acid @ 12gms & 89.5 & 88.5 & $\mathbf{8 9}$ & 110.5 & 121.2 & $\mathbf{1 1 5 . 8 5}$ \\
\hline $\mathbf{4}$ & Naphthalene acetic acid @ 80gms & 84.7 & 84.6 & $\mathbf{8 4 . 6 5}$ & 99.7 & 99.5 & $\mathbf{9 9 . 6}$ \\
\hline $\mathbf{5}$ & Naphthalene acetic acid @ 100gms & 83.2 & 85.3 & $\mathbf{8 4 . 2 5}$ & 101.2 & 101.6 & $\mathbf{1 0 1 . 4}$ \\
\hline $\mathbf{6}$ & Naphthalene acetic acid @ 120gms & 85.7 & 85.2 & $\mathbf{8 5 . 4 5}$ & 104.5 & 104.4 & $\mathbf{1 0 4 . 4 5}$ \\
\hline $\mathbf{7}$ & Control & 84.2 & 84.5 & $\mathbf{8 4 . 3 5}$ & 96.2 & 99.2 & $\mathbf{9 7 . 7}$ \\
\hline
\end{tabular}




\section{Yield Attributes}

\section{A. Tillers/Hill}

It was observed that; tillers/hill increased with the foliar application of Plant Growth Regulators significantly as those were compared with control. Even plant canopy development in transplanted rice take 25 to 40 days depending upon the soil, nutrients availability, irrigation, fertilizer application and environmental factors but it was evaluated that new tillers/hill were sprouted after the application of PGRs. Average maximum tillers/hill were counted (18.5/hill) in T-3 Gibberellic acid GA $\mathrm{G}_{3}$ @ $10 \mathrm{gms} /$ Acre, followed by (17.6/hill) in T-5 Naphthalene acetic acid whereas (11.9/hill) tillers were counted per hill in T-7 Control/Check plot (Table 2).

\section{B. Grain filling percentage}

Results revealed that Grain filling percentage was better than control; there was significant difference between treated and untreated plots. Average maximum grain filling (83.4\%) were recorded in T-5 Naphthalene acetic acid @ $100 \mathrm{ml} /$ Acre followed by $(82.9 \%)$ in $\mathrm{T}-2$ Gibberellic acid
$\mathrm{GA}_{3} @ 10 \mathrm{gms} /$ Acre were recorded whereas average minimum grain filling $(71.3 \%)$ was recorded in T-7 Control under field conditions (Table 2).

\section{Yield}

Foliar exercise of growth regulators significantly increased yield of rice crop under filed conditions. Maximum yield was recorded in 2016-17 $3344.7 \mathrm{~kg} /$ Acre in T-5 Naphthalene acetic acid (NAA) @ 100ml/Acre. Minimum yield (2565.5kgs/Acre) was recorded in 2017-18 in T-7 Control. Over all maximum yield $(3228 \mathrm{kgs} /$ Acre) traced in T-5 Naphthalene acetic acid @ 100ml/Acre followed by (3211.6kgs/Acre) the yield documented in T-2 Gibberellic acid @ 10gm/Acre while T-7 Control produced $2698 \mathrm{~kg} /$ Acre in conducted experiment (Table 3).

\section{Yield Increase Percentage}

It was evaluated that all the treated plots increased yield as they were treated with PGRs. $11.45 \%, 19 \%, 16.99 \%$, $15.45 \%, 19.61 \%$ and $16.26 \%$ recorded in GA3 @ 08gms, $10 \mathrm{gms}$, and $12 \mathrm{gms}$ and NAA @ 80ml, 100ml and $120 \mathrm{ml} /$ Acre respectively (Fig.1).

Table 2. Yield attributes of Rice crop after foliar applications of PGR.

\begin{tabular}{|l|l|l|l|l|l|l|l|}
\hline \multirow{2}{*}{ S. N. } & \multirow{2}{*}{ Treatment } & \multicolumn{2}{|l|}{ Tillers/Hill } & \multicolumn{3}{l|}{ Grain filling \% } \\
\cline { 3 - 8 } & & $\mathbf{1}^{\text {st }}$ Year & $\mathbf{2}^{\text {nd }}$ Year & Average & $\mathbf{1}^{\text {st }}$ Year & $2^{\text {nd }}$ Year & Average \\
\hline $\mathbf{1}$ & Gibberellic acid @ 08gms & 14.5 & 13.7 & 14.1 & 80.3 & 78.2 & 79.25 \\
\hline $\mathbf{2}$ & Gibberellic acid @ 10 gms & 21.5 & 17.5 & 18.5 & 81.7 & 84.1 & 82.9 \\
\hline $\mathbf{3}$ & Gibberellic acid @ 12 gms & 18.7 & 15.1 & 16.9 & 80.5 & 83.7 & 82.1 \\
\hline $\mathbf{4}$ & Naphthalene acetic acid @ 80ml & 15.3 & 14.2 & 14.75 & 84.3 & 82.5 & 83.4 \\
\hline $\mathbf{5}$ & Naphthalene acetic acid @ 100ml & 18.5 & 16.7 & 17.6 & 92.2 & 87.7 & 81.95 \\
\hline $\mathbf{6}$ & Naphthalene acetic acid @ 120ml & 15.4 & 14.2 & 14.8 & 80.2 & 78.2 & 79.2 \\
\hline $\mathbf{7}$ & Control & 12.3 & 11.5 & 11.9 & 70.2 & 72.4 & 71.3 \\
\hline
\end{tabular}

Table 3: Effect of PGRs ( $\mathrm{GA}_{3}$ and NAA different doses) on the yield of rice crop under field conditions.

\begin{tabular}{|l|l|l|l|l|}
\hline $\mathbf{S .} \mathbf{N}$. & Treatment/Acre & $\mathbf{1}^{\text {st }}$ Year & $\mathbf{2}^{\text {nd }}$ year & Mean \\
\hline $\mathbf{1}$ & Gibberellic acid @ 08gms & 3011.5 & 3004.3 & $3007.9 \pm 5.091$ \\
\hline $\mathbf{2}$ & Gibberellic acid @ 10gms & 3321.7 & 3101.5 & $3211.6 \pm 155.704$ \\
\hline $\mathbf{3}$ & Gibberellic acid @ 12gms & 3244.4 & 3070.7 & $3157.5 \pm 122.824$ \\
\hline $\mathbf{4}$ & Naphthalene acetic acid @ 80ml & 3208.4 & 3025.5 & $3116.9 \pm 129.329$ \\
\hline $\mathbf{5}$ & Naphthalene acetic acid @ 100ml & 3344.7 & 3111.3 & $3228.0 \pm 165.038$ \\
\hline $\mathbf{6}$ & Naphthalene acetic acid @ 120ml & 3220.5 & 3092.5 & $3156.5 \pm 90.509$ \\
\hline $\mathbf{7}$ & Control & 2832 & 2565.5 & $2698.75 \pm 188.44$ \\
\hline
\end{tabular}




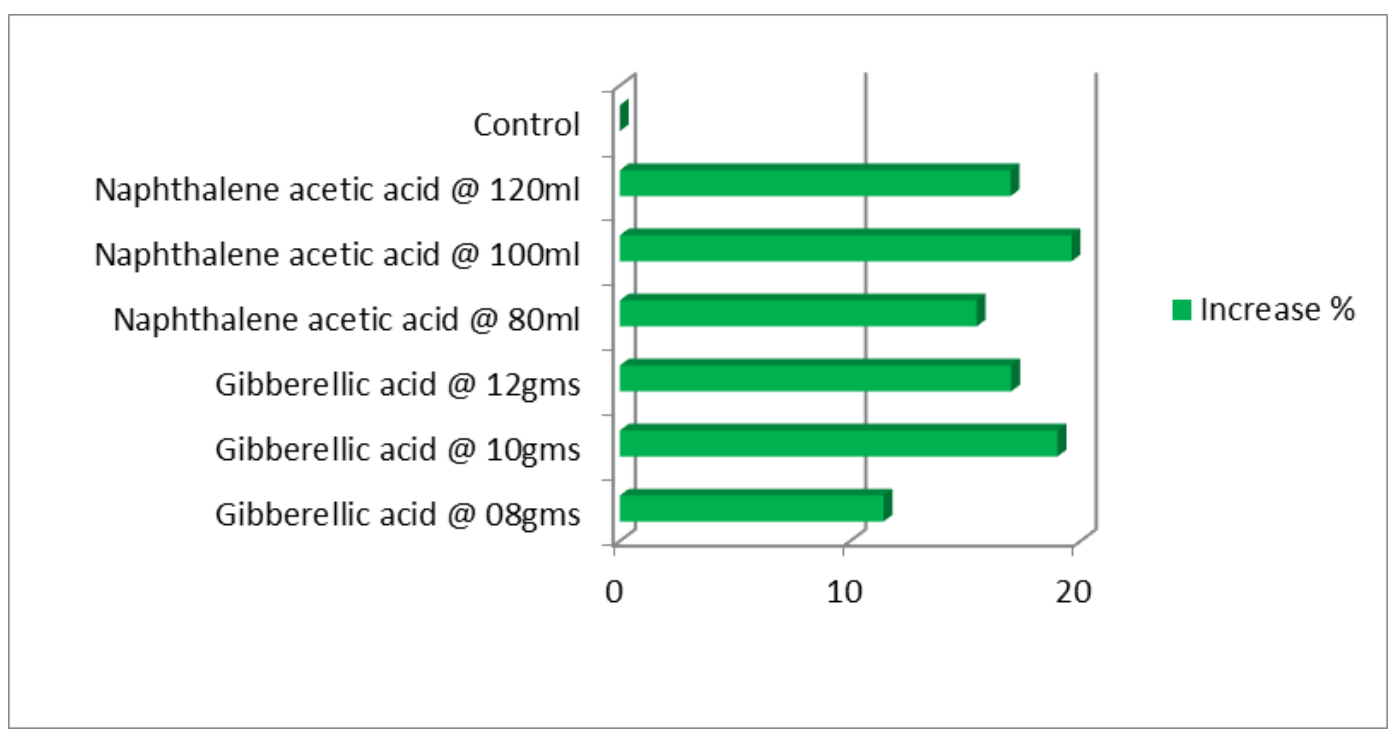

Fig. 1: Average yield increase percentage after foliar application of $\mathrm{GA}_{3}$ and NAA

\section{Discussion}

The experiment was design with two plant growth regulators with three doses of each one, doses were applied to evaluate their impact on growth, yield attributes and the production obtained per acre from treated plots, Naphthalene acetic acid (NAA) foliar applications produced no significant difference on crop maturity days while NAA shown good impact on plant height. Plant canopy development numbers of tiller were increased in NAA treated plots. Maximum yield increase percentage $19.61 \%$ was recorded at NNA foliar application on $100 \mathrm{ml} /$ Acre.

Experiment shown that, leaves/plant, plant height and tillers/plant were found to boost in 100 and 200ppm naphthalene acetic acid (NAA). Rate of growth of plant was heights at early stage and then declined. 100ppm NAA produced better stimulation (Nargis and Golam, 2011). Similarly, good chlorophyll content with better crop canopy and increase grains/panicle with good grain weight ended significantly yield increase with the foliar spray of NAA (Grewal and Gill, 1986). It was evaluated that the maximum plant tallness was recorded due to 200ppm. Numbers of tillers were found to increase due to 100ppm NAA. Yield attributes increased in both 100 and 200 ppm (Golam and Nargis, 2011). Results found that 1- naphthalene acetic acid NAA a synthetic auxin, when applied in spray influences the life cycle if rice via metabolic processes to manifest beneficially through translocation assimilates the effect of NAA on the growth, yield attributes and yield (Basu, 2016). Investigations of various concentrations of Naphthalene acetic acid at $25 \mathrm{mg} / 1,50 \mathrm{mg} / 1,75 \mathrm{mg} / 1$ and $100 \mathrm{mg} / 1$ to test the effect on the growth and yield. Spike length, grain/spike and 1000 grain weight greater than control. NAA 50mg/l increases $12.24 \%$ higher over control (Nargis and Golam 2013).
Gibberellic acid $\left(\mathrm{GA}_{3}\right)$ was another PGR applied to weigh up its efficiency and contribution for surveillance, better development and yield increase of rice crop under field conditions. It was found that GA3 was impressive and contributed significantly in rice plant growth and yield increase as well. Plant height number of tillers/hill, number of filled grains and yield increased percentage was significantly better than control under field conditions.

Results revealed that the PGR's superior value in all stages of crop with respect of control. Yield and yield attributes were found superior with foliar application of GA3 (200ppm) (Mayanak et al., 2018). The growth and yield parameters of rice like tallness of plant, and tiller per hill, flag leaf index, spikes/meter and filled grains per panicle were strikingly impressive due to Gibberellic acid @25g h-1 in both seasons. The lowest growth characteristic of yield attributes and grain yield were recorded in control (no foliar spray) (Ramesh et al., 2019). The use of a variety of plant growth hormones considerably boosted seed yield with a range of $14.85 \mathrm{~g}$ to $23.54 \mathrm{~g}$. Treatment; $\mathrm{T} 2-\mathrm{GA}_{3} 45 \mathrm{~g}$, T1 -GA3 30g, T5- NAA $200 \mathrm{~g}$ and T3- NAA $100 \mathrm{~g}$. The application of growth regulators significantly increased yield components (Tiwari 2011). GA3 application was very effective in increasing seed set rate and seed yield. 225 and $150 \mathrm{~g} / \mathrm{h}$ of GA3 were found the most effective and economical (Gavino et al, 2008).

\section{Conclusion}

Gibberellic acid and Naphthalene acetic acid both PGRs performed on different doses when applied with foliar applications three times $1^{\text {st }}$ after 30 days of transplanting and other two with twenty days interval. Difference was clearly observed as the treated plots were compared with control. Gibberellic acid $\left(\mathrm{GA}_{3}\right)$ at $10 \mathrm{grams} / \mathrm{acre}$ and 
Naphthalene acetic acid (NAA) at $100 \mathrm{ml} /$ acre was found to be the best among all treatments in rice crop.

\section{Conflict of Interest}

The authors do not have any conflict of interest with the present publication

\section{Acknowledgement}

The authors are grateful to the necessary support given by Ashraf Ali Soomro (Director) Rice Research Institute Dokri, Larkana, Pakistan.

\section{References}

Arteca RN (1995) Plant Growth Substances: Principles and applications. (AOSA. 1981. Rules for testing seeds. Proc. Assoc. of Official Seed Anal. :60: 1-126) Chapman and Hall, New York, USA. 332 pp.

Asborno MD, AA Vidal, R. Bezus and J. Beltrano (1999) Rice: temperature and gibberelic acid effect on initial growth stages. Agro Ciencia (Spanish, Abstract in English) 15(1): 47-53.

Basu chaudhri P (2016) 1. Naphthalene acetic acid in rice cultivation. Current Science. 110 (1): 52-56. DOI: $10.18520 / \mathrm{cs} / \mathrm{v} 110 / \mathrm{i} 1 / 52-56$

Chhonkar VS and SN Singh (1959) Effect of Naphthalene acetic acid on growth, quality and yield of tomato. Ind. J. Hort. 16(4): 236-242.

Dimitrio PN, IC Tzanetoes, PN Georgia and P Nikos (2008) A portable sensor for the rapid detection of naphthalene acetic acid in fruits and vegetables using stabilizied in air lipid flims with incorporated auxin -binding protein 1 recepter. Talanta 77:786-792. DOI: $\underline{10.1016 / j . t a l a n t a .2008 .07 .030}$

Fahad S., Hussain S., Saud S., Khan F., Hassan S., Amanullah A., et al. (2015) Exogenously applied plant growth regulators affect heat-stressed rice pollens.J. Agron. Crop Sci. 202:139-150. DOI: https://doi.org/10.1111/jac.12148

Gavino RB, Pi Y and Abon Jr. CC (2008) Application of gibberellic acid $\left(\mathrm{GA}_{3}\right)$ in dosage for three hybrid rice seed production in the Philippines. Journal of Agriculture Technology:183-192.

Golam Adam AMM and Nargis Jahan (2011) Effect of Naphthalene acetic acid on yield attributes and Yield of two varieties of rice (Oryza sativa L.). Bagladesh J. Bot. 40(1):97-100. DOI: $10.3329 /$ bjb.v40i1.8004

Grewal HS and HS Gill (1986) Influence of NAA and nitrogen on the growth and yield of late planted paddy (Oryza sativa L.) The Journal of Agricultural Science 106(1):37-40. DOI: $10.1017 / \mathrm{S} 0021859600061694$

IPCC (2007) "Summary for policymakers," in Climate Change: Impacts, Adaptation and Vulnerability. Contribution of Working Group II to the Fourth Assessment Report of the Intergovernmental Panel on Climate Change, eds M. L. Parry, O. F. Canziani, J. P. Alutikof, P. J. Van der Linden,
C. E. Hanson (Cambridge: Cambridge University Press): $81-82$.

Jagadish S, Cairns J, Lafitte R, Wheeler T, Price A and Craufurd $P$ (2010) Genetic analysis of heat tolerance at anthesis in rice. Crop $\quad S c i . \quad 50: 1633-1641 . \quad$ DOI: https://doi.org/10.2135/cropsci2009.09.0516

Lobell DB and Field CB (2007) Global scale climate-crop yield relationships and the impacts of recent warming. Environ. Res. 2:014002. DOI: https://doi.org/10.1088/17489326/2/1/014002

Mayanak Partap, Pardip kumar Saini, Vikas Yadav and RK Yadav (2018) Effect of foliar application of PGRs on growth, yield and yield attributes of Rice (Oryza sativa L.) under salt stress condition. Journal of Pharmacognosy and phytochemistry.2:268-272

Nargis Jahan and AMM Golam Adam (2011) Comparative Growth Analysis of two Varieties of Rice Following Naphthalene Acetic Acid. Journal of Bangladesh Academy of Sciences 35(1):113-120. DOI: 10.3329/jbas.v35i1.7976

Nargis Jahan and AMM Golam Adam (2013) Growth and yield response of BARI Gom-26 (Triticum astivum L.) to naphthalene acetic acid. Journal of Biological Sciences 22(2): 119-125Shaikh FM, Jamali MB, Shaikh K, Abdi AR (2011) WTO reforms and rice market in Pakistan. Int. J. Asian Soc. Sci. 1(3):45-51. DOI: /10.3329/dujbs.v22i2.46287

Prasad PVV., Boote, KJ., Allen LH., Sheehy JE., and Thomas JMG. (2006). Species, ecotype and cultivar differences in spikelet fertility and harvest index of rice in response to high temperature stress. Field Crops Res. 95:398-411. DOI: $10.1016 /$ j.fcr.2005.04.008

Ramesh S, P Sudhakar, S Elankavi, K Suessndran and S Jawahar (2019) Effect of Gibberellic acid GA3 on growth and yield of Rice (Oryza sativa L.) Plant Archives 19(1):1369-1372.

Salisbury FB and CW. Ross. (1992) Plant Physiology. Fourth Edition. Wadworth Publ. Co., Belmont. 682 pp.

Timmer CP (2010) The Changing Role of Rice in Asia's Food Security. Asian Development Bank, Working paper series, 15, September, 19pp.

Tiwari DK, P Pandey, SP Giri and J L Dwivedi (2011) Effect of $\mathrm{GA}_{3}$ and other Plant Growth regulators on Hybrid Seed Production. Asian Journal of Plant Sciences 10(2):133139. DOI: $10.3923 /$ ajps.2011.133.139

Walia H, Wilson, C, Condamine P, Liu X, Ismail AM and Close TJ (2007) Large-scale expression profiling and physiological characterization of Jasmonic Acid-Mediated adaptation of Barley to salinity stress. Plant Cell Environ. 30:410-421. Doi: https://doi.org/10.1111/j.1365-3040.2006.01628

Yoshida S, Satake T and Mackill DS (1981) "High temperature stress in rice," (Laguna). in IRRI Research Paper Series $67 \mathrm{pp}$. 